Tér és Társadalom 18. évf. 2004/1. 93-106. p.

Tér és Társadalom

XVIII. évf. 2004

1:93-106

\title{
GYORS TÉNYKÉP
}

\section{A TŐKEÁRAMLÁS EGYIK LEHETSÉGES CSATORNÁJA A TERMŐFÖLDALAPÚ JELZÁLOGHITELEZÉS}

\author{
(One of the Possible Channels of Capital Inflow is Land Based \\ Mortgage Credit)
}

KÖKÉNYESI LÁSZLÓ

Kulcsszavak:

regionális különbségek tökeáramlás jelzáloghitelezés termöföld családi gazdaság

Jelen tanulmány arra a következtetésre jut, hogy a jelzáloghitelezés által létrehozott tökeáramlásban hăttérbe szorulnak a kistelepullések. A szerzö véleménye szerint a termöföldalapú jelzaloghitelezés a falvak felé fordíthatná a tökeáramlást. A szerzö a regisztrált családi gazdálkodók adataiból és az FHB hitelfeltételeiböl kiindulva modellszámitást mutat be a gazdák termöföldalapú hitelezhetöségére. A modellszámitás eredménye, hogy egy átlagos gazdálkodó $6,7 \mathrm{M} \mathrm{Ft} \mathrm{termöföldalapú} \mathrm{jelzáloghitelt} \mathrm{lenne}$ kêpes felvenni. Elégséges jövedelem igazolása nélkull 500 eFt/ha földárral számolva 10 hektár, 800 EFt/ha-os átlagárral számolva pedig 7 hektär a hitelezhetöség alsó határa. Több mint $72 \mathrm{Mrd}$ Ft földalapú jelzáloghitel lenne kihelyezhetö a családi gazdálkodókhoz.

Az elmúlt években a bankrendszerben az egyik legjelentösebb növekedés a lakáscélú jelzáloghitelek piacán következett be. A jelzáloglevélhez kötődő állami támogatás bevezetése és az infláció uttemének csökkenése miatti kamatlábcsökkenés más piaci folyamatok kedvező hatásai mellett - a jelzáloghitel-állomány dinamikus növekedését idézték elö (Várhegyi 2002). A személyi jövedelemadóról szóló törvénybe épített adókedvezmény mértékének növekedése is kedvezỏen hatott a hitelkeresletre. A Földhitel- és Jelzálogbank Rt. - mint a hazai jelzáloghitelezés kiemelkedö intézménye - folyamatosan növelte hitelkihelyezéseit, miközben eredményessége javult, töke-megfelelési mutatója pedig $26 \%$ fölé emelkedett ( $F H B R$ Rt. 2000; 2002).

A lakáscélú kihelyezések növekedése háttérbe szorította az egyéb célú kihelyezéseket (pl. ipari ingatlan vagy termőföld fedezete mellett nyújtott hitelek). A termöföld fedezetủ kintlévőség az FHB hitelportfóliójában nem éri el a 0,7\%-ot.

Ha a jelzáloghitelezést, mint tökeáramlási csatornát tekintjük, akkor vizsgálhatjuk, hogy milyen irányú tơkeáramlást hoz létre. A hitelintézetek ủzleti titokra hivatkozva nem publikálnak olyan adatokat, amelyek a hitelfelvevő lakhelye szerint, illetve a finanszírozott hitelcél helye szerinti bontásban tükrözné a hitelportfóliót.

A hivatalos lakásstatisztika alapján azonban tudunk következtetni a kihelyezések területi szerkezetére. Az elmúlt évek lakásépítési adatait mutatja az 1. táblázat. 
Kökényesi László : A tőkeáramlás egyik lehetséges csatornája a termőföldalapú jelzáloghitelezés. Tér és Társadalom 18. évf. 2004/1. 93-106. p.

94 Gyors ténykép

TÉT XVIII. évf. 2004

1. TÁBLÁZAT
A lakásépítés alakulasa
(The Development of Housing)

\begin{tabular}{|c|c|c|c|c|c|c|}
\hline Epített lakas, darab & 1990 & 1995 & 1999 & 2000 & 2001 & 2002 \\
\hline Budapesten & 6985 & 2945 & 2904 & 3113 & 4434 & 6473 \\
\hline A többi városban & 19640 & 9494 & 8635 & 9760 & 13685 & 15853 \\
\hline Községben & 17146 & 7884 & 7748 & 8710 & 9935 & 9185 \\
\hline Összesen & 43771 & 20323 & 19287 & 21583 & 28054 & 31511 \\
\hline Épített lakás (\%) & 1990 & 1995 & 1999 & 2000 & 2001 & 2002 \\
\hline Budapesten & 16 & 14 & 15 & 14 & 16 & 21 \\
\hline A többi városban & 45 & 47 & 45 & 45 & 49 & 50 \\
\hline Községben & 39 & 39 & 40 & 40 & 35 & 29 \\
\hline Összesen & 100 & 100 & 100 & 100 & 100 & 100 \\
\hline $\begin{array}{c}\text { Épített lakás } \\
\text { (elözó év }=100 \% \text { ) }\end{array}$ & & & & 2000 & 2001 & 2002 \\
\hline Budapesten & & & & $107 \%$ & $142 \%$ & $146 \%$ \\
\hline A többi városban & & & & $113 \%$ & $140 \%$ & $116 \%$ \\
\hline Községben & & & & $112 \%$ & $114 \%$ & $92 \%$ \\
\hline Összesen & & & & $112 \%$ & $130 \%$ & $112 \%$ \\
\hline $\begin{array}{c}\text { Épített lakás } \\
(1999=100 \%) \\
\end{array}$ & & & & 2000 & 2001 & 2002 \\
\hline Budapesten & & & & $107 \%$ & $153 \%$ & $223 \%$ \\
\hline A többi városban & & & & $113 \%$ & $158 \%$ & $184 \%$ \\
\hline Községben & & & & $112 \%$ & $128 \%$ & $119 \%$ \\
\hline Összesen & & & & $112 \%$ & $145 \%$ & $163 \%$ \\
\hline
\end{tabular}

Forrás: Saját szămítások a Magyar Statisztikai Évkönyv (2002) 6.3 táblázata alapjăn.

Az adatok azt tükrözik, hogy 2001-ben és 2002-ben az épített lakások számát tekintve 40,2\%-ról 29\%-ra csökkent a községekben megvalósult kivitelezések részaránya, miközben dinamikusan nőtt a városi lakásépítések száma. Ha megyék és régiók szerint is vizsgáljuk a lakásépítések alakulását, akkor még nagyobb területi különbségek figyelhetỏek meg. Amint a 2. táblázat mutatja, a Györ-Moson-Sopron megyei városokban az 1000 lakosra esö épített lakások száma (7,1 lakás/efö) több mint hétszerese a Borsod-Abaúj-Zemplén megyei városokban épített lakások számának (1 lakás/efö), és több mint tizennégyszer akkora, mint a Békés megyei községekben épített lakások számaránya (0,5 lakás/efö). Az is igaz, hogy vannak megyék, ahol a községek adatai jobbak a városok építési adatainál (pl. Pest és Fejér megye), de összességében mégis megállapitható, hogy lakosságszám szerint alulreprezentáltak a lakásépítésben a községek. 
Tekintettel arra, hogy az elmúlt években az épített lakások túlnyomó többsége lakáscélú hitelfelvétel mellett valósult meg, úgy gondoljuk, hogy az épített lakások területi eloszlása jó indikátor a lakáscélú hitelek áramlási irányának a meghatározásához. Szerintünk a használt lakások piacán kialakult hitelfelvétel melletti forgalom, az átlagos építési költségek területi különbségeinek alakulása csak megerösítheti azt a vélekedést, hogy a lakáscélú hitelek nem lakosságarányosan oszlanak meg. A jelzáloghitelek terén háttérbe szorulnak a kistelepülések. A hitelállomány elsősorban a fövárosban, a megyeszékhelyeken és egyéb városokban megvalósított beruházásokat finanszíroz. A falvakba a lakosságarányosnál kevesebb jelzáloghitel, és ezzel együtt kevesebb támogatás áramlik.

$\mathrm{Az}$ állami költségvetés jelentös deficitje miatti jogszabályváltozások és más piaci folyamatok miatt várható, hogy a közeljövőben lelassul, megtorpan a lakáscélú jelzáloghitelek növekedési üteme. Ha a lakáscélú jelzáloghitelezés piacának további bövülése valóban korlátokba ütközik, miközben a hitelezök oldalán bövül a szereplök köre, akkor szükségképpen várható, hogy egyrészt erösödni fog a hitelfelvevö ügyfelekért folyó verseny, másrészt új potenciális piacok felkutatására és új célpiacok megnyitására fognak törekedni a hitelintézetek, mely változás a tökeáramlás irányát is megváltoztathatja.

Tanulmányunkban egy lehetséges „régi-új” célpiaccal, a termőföldalapú jelzáloghitelezéssel foglalkozunk. A regisztrált családi gazdálkodókról rendelkezésünkre álló információk alapján modellszámítást végeztünk a földjelzálog-alapú finanszírozhatóságukra vonatkozóan. Az alkotott modell feltételeit a 3. táblázatban, a használatával kapott eredményeket pedig a 4. és 5. táblázatban foglaltuk össze.

A számításokhoz konstruált kétváltozós lineáris modellt egy függő változó, egy független változó valamint hét paraméter alkotja. A paraméterek között kettőnek az értéke független a hiteligénylők összetételétöl és konkrét jellemzőitől. Az egyik a hitelbiztosítékiérték-arány a piaci ár százalékában kifejezve, a másik a hitelezhetöség mértéke a hitelbiztosítéki-érték (HBÉ) százalékában kifejezve. Az elöző konkrét értékét a földértékelések során a szakmában elfogadott és megszokott gyakorlat alakította ki, a másik pedig a jelzálogbank által meghatározott, és a termékismertetőkben közzétett, de ugyancsak szakmai érvekre alapozott érték. E két paramétert addig, amíg a gyakorlat meg nem változik, illetve amíg a hitelfeltételeket meg nem változtatják, konstansnak is tekinthetjük. A további öt paraméter viszont „valódi” paraméternek tekinthető, és értékük annak megfelelően változik, hogy a modell alkalmazása a hiteligénylök milyen körére terjed ki, illetve, hogy a hiteligénylök milyen jellemzökkel bírnak.

A modell a paraméterek megfelelö megválasztásával és egyszerüségénél fogva is alkalmas arra, hogy segítségével meghatározzuk egy konkrét gazda hitelezhetöségét valamely jelzálogbank adott feltételrendszerében. Alkalmazásával meghatározható a regisztrált családi gazdaságok egy részének, vagy egészének a termőföldbázisalapú jelzálog hitelezhetösége is. 
Kökényesi László : A tőkeáramlás egyik lehetséges csatornája a termőföldalapú jelzáloghitelezés.

Tér és Társadalom 18. évf. 2004/1. 93-106. p.

TÉT XVIII. évf. 2004 @ 1

Gyors ténykép

97

\section{TÁBLÁZAT}

Modellszámítás a regisztrált családi gazdálkodók termőföldalapú jelzálog-

hitelezhetöségéröl az FHB jelenlegi termékpalettájának feltételei szerint

(Model Calculation on the Land Based Mortgage Credit of Registered Farmers by the Conditions of FHB's Current Products)

A modell feltételei az FHB-ra vonatkozóan:

1) Csak a termékismertetőben rögzített feltételeket követeli meg.

2) A feltételeknek megfelelő minden hiteligényt ki tud, és ki akar elégíteni, egyéb feltételt nem támaszt.

3) Nem alkalmazza a hitelbiztosítéki-értékre (HBÉ) vonatkozó 4 MFt-os minimális egyedi érték követelményét.

A modell feltételei a családi gazdálkodóra vonatkozóan:

1) Minden gazda, aki elfogadja a banki kondíciókat, megfizeti az egyéb díjakat.

2) Az életkor szerint egyenletesen oszlik el a földtulajdon.

3) Hiteligénylés vagy elutasítás szerint egyenletesen oszlik el a földtulajdon.

4) Minden gazdánál elfogadják rendszeres jövedelemszerző tevékenységének igazolását.

5) Minden gazda megköti a szükséges vagyonbiztosítást.

6) A hitelt közerkölcsöt nem sértö és jogszabályba nem ütköző vállalkozási célra kívánja fordítani.

7) A gazdálkodók az egyéb hitelnyújtási feltételeket is teljesítik.

8) Az életkor és a hiteligénylési szándék között nincs szignifikáns kapcsolat.

A modell feltételei a családi gazdálkodó termöföldjére vonatkozóan:

1) A családi gazdaságok termöföldjei rendezett jogi státusúak, per-, igény- és tehermentesek.

2) Az ingatlanok tényleges állapota egyezik az ingatlan-nyilvántartás adataival.

3) Minden termöföld önállóan forgalomképes és 180 napon belül értékesíthetőnek minösül.

4) Nincs akadálya az elsö ranghelyü jelzálogjog, ill. elidegenítési és terhelési tilalom bejegyzésének.

5) A termőföld jellemzöi és a gazda életkora között nincs szignifikáns kapcsolat.

6) A földterületek mérete azonos eloszlást mutat a hitelt igénylők és nem igénylök között.

Forrás: Saját szerkesztés.

A modell segítséget nyújthat ahhoz is, hogy a jelzáloghitelezés támogatási feltételeit kidolgozzák, hiszen használatával megbecsülhető a hitelezhetö földbázis, meghatározható a várható hitelkihelyezés értéke, és ebből becsülhető a várható támogatási igény is.

Munkánkban a Földhitel- és Jelzálogbank (FHB) feltételrendszerére alapozva alkalmaztuk a modellt, és végeztük el a számításokat. 
A modell változói és paraméterei az FHB hitelezési feltételeihez igazodóan a következők:

\section{Változók:}

- Függő változó: A termőföldfedezet mellett felvehető jelzáloghitel eFt-ban kifejezett nagysága (megjelölése: Felvehető jelzáloghitel).

Értelmezése a független változóhoz kapcsolódik. Amely sokaságra vonatkozik a független változó, ugyanarra a sokaságra vonatkozik a függő változó értéke is.

- Független változó: Az összes földterület hektárban (jele: a). Attól függően töltendő ki a megfelelö értékkel, hogy egy konkrét személyre, egy átlagos gazdára, vagy az egész gazda-sokaságra, esetleg részsokaságra kívánunk-e számításokat végezni.

\section{Paraméterek:}

1) Az 5 ha egybefüggö területet elérö földek aránya \%-ban (jele: b).

Az FHB nem fogadja el fedezet gyanánt az 5 hektárnál kisebb területeket akkor sem, ha összességében jelentős méretủ és jelentős értékủ, ezért kell ezzel a paraméterrel leszükíteni a művelés alatt álló összes földterületet. A paraméter értékét tizedes tört formában kell megadni.

2) A 18-60 év közötti gazdák aránya \%-ban (jele: c).

Szigorú feltétel, hogy a hitelfelvevő a hitel teljes futamideje alatt 65 év alatti legyen. Ha ez nem teljesül, akkor nagy értékủ földterületek sem válhatnak fedezetté. Mivel 5 és 15 év közöttiek a kihelyezések, ezért a hitelbírálatkor a gazda nem tölthetti be az 50. illetve a 60 . évét. Ha egy konkrét személyre, vagy az átlagos személyre végzünk számítást, akkor a tényleges, illetve a számtani átlaggal számolt életkornak megfelelően kell a paraméternek értéket adni. Ha alatta marad az értéknek, akkor a paraméter értéke $100 \%$, ha meghaladja a kritikus értéket, akkor a paramétert 0\%-ra kell beállítani tizedes tört formában.

3) Hiteligénylők aránya a hitelezhetök között \%-ban (jele: d).

A független változóként konkretizált potenciális földterületet az 1. és 2. pontban leszúkítettük az elfogadható, hitelezhető körre, de nem biztos, hogy közülük mindenki kér is jelzáloghitelt. Ebben a pontban szükítjük a hiteligénylök körére. Ha egy konkrét személyre, vagy az átlagos személyre végzünk számítást, akkor kérelem esetén $100 \%$, hitelkérelem be nem nyújtása esetén $0 \%$ a paraméter értéke, tizedes tört formában.

4) Hitelkapacitás kihasználása (\%) (jele: e).

$\mathrm{Az}$ eddig megfelelö személyek, ha adnak is be hitelkérelmet, akkor sem biztos, hogy az általuk maximálisan felvehető hitelt kérik. Tudnunk kell, hogy hány \%-ban merítik ki lehetöségeiket. Ennek egyformán lehet értéket adni akkor is, ha egy-egy személyre, és akkor is, ha rész- vagy teljes sokaságra kívánunk számítást végezni. Az értéket tizedes tört formában kell megadni. 
Kökényesi László : A tökeáramlás egyik lehetséges csatornája a termöföldalapú jelzáloghitelezés.

Tér és Társadalom 18. évf. 2004/1. 93-106. p.

TÉT XVIII. évf. 2004 - 1

Gyors ténykép

99

5) A föld átlagos piaci ára eFt/ha-ban (jele: f).

Miután a személyek életkora és hitelfelvételi szándéka, továbbá a föld aprózottsága szerint behatároltuk a hitelezhetỏ földterületet, most meg kell határozni az értékét is. Ehhez használjuk a hektáronkénti átlagár paramétert. Egyedi árakból, súlyozott számtani átlaggal javasolt ezt kiszámolni, és a modellhez eFt/ha-ban megadni.

6) Hitelbiztosítékiérték-arány a piaci ár \%-ában (jele: g).

A jelzálogbank nem a teljes aktuális piaci értéket fogadja el biztosítéki értéknek, mert adott esetben az értékesítésnek gyorsan kell megtörténnie, ami csak piacinál alacsonyabb ár elérését teszi lehetỏvé. Általában a piaci érték 80\%-a körül határozzák meg a HBÉ-et. Amekkora arányt a konkrét esetben alkalmaznak, azt az értéket kell megadni tizedes tört formában.

7) Hitelezhetőség aránya a HBÉ \%-ában (jele: h).

A HBÉ-nek nem egészét hajlandó kihitelezni a jelzálogbank, csak egy részét, hogy az esetleges késỏbbi piaci árváltozások, árcsökkenések esetében is kellö fedezetet jelentsen az ingatlan. Jelenleg az FHB konkrét esettöl függően csak a HBÉ 35-60\%-áig hajlandó hitelt nyújtani.

A felsorolt paraméterek segítségével a következó matematikai formulával tudjuk kiszámítani a termőföldfedezet mellett felvehetỏ jelzáloghitel eFt-ban kifejezett nagyságát:

\section{Felvehetó jelzáloghitel $=a x b \times c \times d \times$ exf $x g \times h$}

A modell alkalmazásához vagy ismerni kell az elemzés alapjául szolgáló „,gazdasokaság" pontos jellemzőit, vagy becsléseket kell végezni a modellhez fontos jellemzőkre vonatkozóan, illetve feltételezésekkel is élhetünk. Egy átlagos jellemzőkkel bíró gazda jelzáloghitel-potenciáljára vonatkozó számításoknál a következő adatokat, illetve feltételezéseket használtuk:

Az átlagos családi gazdálkodó 60 ha területen gazdálkodik, amelynek 70\%-a legalább

5 ha-os egybefüggó szántóterületet alkot, földjei átlagos piaci értéke $500 \mathrm{eFtha}$, és a gazda életkorát tekintve megfelel az FHB feltételének. Feltételeztük továbbá, hogy egy ilyen gazda 100\%-ban ki kívánja használni hitelpotenciálját, de megfelelő (számításaink szerint tízéves futamidö, 50\%-os terhelhetőség és az FHB jelenlegi kondíciói mellett havi nettó $250 \mathrm{eFt}$ ) jỏvedelemigazolást nem tud becsatolni a termőföld alapú jelzáloghitel igénylése során.

A modell felhasználásával elvégzett számítások azt mutatják, hogy egy ilyen átlagos gazda 6,7 MFt jelzáloghitelt kaphatna az FHB-töl (4. táblázat), feltéve, hogy a 3. táblázatban foglalt egyéb feltételek is teljesülnek. Ez az érték meghaladja a mai lakáscélú hitelek 4-5 MFt-os átlagos mértékét. Jelentős beruházáshoz ugyan nem elegendó, de például tartós forgóeszköz lekötés finanszírozásához, vagy gépvásárláshoz jó kiegészítő forrásul szolgálhatna. 


\section{TÁBLÁZAT}

Egy konkrét gazda hitelezési lehetösége

(The Credit Possibilities of a Real Farmer)

\begin{tabular}{|c|c|c|c|}
\hline \multicolumn{2}{|c|}{ A modellszámítás változói és paraméterei } & \multicolumn{2}{|c|}{$\begin{array}{c}\text { Kihelyezhetö jelzáloghitel } \\
\text { számítása }\end{array}$} \\
\hline 1. Összes földterület (ha) & 50 & Összes földterület (ha) & 60 \\
\hline $\begin{array}{l}\text { 2. Ebböl } 5 \text { ha egybefüggö } \\
\text { szántóterületet elérö föl- } \\
\text { dek aránya (\%) }\end{array}$ & 70 & $\begin{array}{l}\text { Ebböl } 5 \text { ha és nagyobb } \\
\text { szántóföldterület (ha) }\end{array}$ & 42 \\
\hline $\begin{array}{l}\text { 3. 18-60 év közöttiek aránya } \\
(\%)\end{array}$ & 100 & $\begin{array}{l}\text { Ebböl 18-60 év közöttiek } \\
\text { területe (ha) }\end{array}$ & 42 \\
\hline $\begin{array}{l}\text { 4. Hitelkérök aránya (\%) (hi- } \\
\text { telezhetökön belül) }\end{array}$ & 100 & $\begin{array}{l}\text { Ebböl hitelkérök területe } \\
\text { (ha) }\end{array}$ & 42 \\
\hline $\begin{array}{l}\text { 5. Hitelkapacitás kihasználása } \\
(\%) \text { (hitelezhetőkön és } \\
\text { hitelkérökön belül) }\end{array}$ & 100 & $\begin{array}{l}\text { Hitelezhetö földterület } \\
\text { (ha) }\end{array}$ & 42 \\
\hline 6. Föld piaci átlagára (eFt/ha) & 500 & $\begin{array}{l}\text { Föld piaci átlagára } \\
\text { (eFt/ha) }\end{array}$ & 500 \\
\hline 7. HBÉ-arány (piaci ár \%-a) & 80 & $\begin{array}{l}\text { Hitelezhetö földek piaci } \\
\text { értéke (eFt) }\end{array}$ & 21000 \\
\hline 8. Hitelezhetőség (HBÉ \%-a) & 40 & HBÉ-arány (piaci ár \%-a) & 80 \\
\hline & & HBÉ (eFt) & 16800 \\
\hline & & $\begin{array}{l}\text { Hitelezhetöség } \\
\text { (HBÉ\%-a) }\end{array}$ & 40 \\
\hline & & $\begin{array}{l}\text { Nyújtható hitel összege } \\
(\text { eFt) }\end{array}$ & 6720 \\
\hline
\end{tabular}

A paraméterek tetszőlegesen változtathatóak.

Forrás: Alapadatok az FVM-től.

Figyelembe véve, hogy az FHB-nál az ilyen célú hitel minimális összege 1,5 MFt, így meghatározható a minimálisan szükséges földterület. Ezek szerint - továbbra is az $500 \mathrm{eFt}$ /ha földárral és megfelelö jövedelemigazolás nélkül 35\% hitelezhetőségi aránnyal számolva - 10 hektár alatt nem hitelképes az ügyfél. Ha viszont feltételezzük, hogy jó minőségủ termőföldjének piaci értéke eléri a 800 eFt/ha-os átlagárat, akkor ceteris paribus a hitelezhetöség alsó határa 7 hektárra csökken. Elégséges jövedelem igazolásával a hitelezhetőség aránya $60 \%$, így egy 5 hektáros szántó fedezetével (kb. havi nettó $75000 \mathrm{Ft}$ jövedelemigazolás mellett) $625 \mathrm{eFt} / \mathrm{ha}$ földár esetén már van lehetőség 1,5 MFt földalapú jelzáloghitel felvételére.

A paraméterek és a modell feltételei szerint megyénként, régiónként és országosan is meghatároztuk a kihelyezhető jelzáloghitel nagyságát. Azt az eredményt kaptuk, hogy összességében több mint $72 \mathrm{Mrd} \mathrm{Ft} \mathrm{jelzáloghitel} \mathrm{lenne} \mathrm{kihelyezhetö} \mathrm{a}$ családi gazdálkodókhoz. Legnagyobb hitelre Észak-Alföld (16,7 Mrd Ft) és DélAlföld (15,1 Mrd Ft) számíthatna. A megyék közül kiemelkedik Jász-NagykunSzolnok megye (6,2 Mrd Ft) (5. táblázat). 
Kökényesi László : A tőkeáramlás egyik lehetséges csatornája a termőföldalapú jelzáloghitelezés.

Tér és Társadalom 18. évf. 2004/1. 93-106. p.

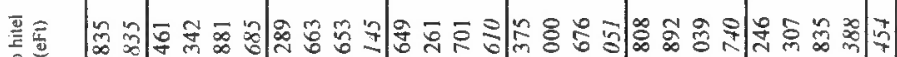

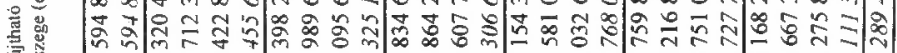

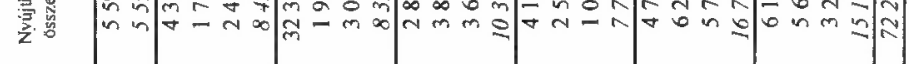

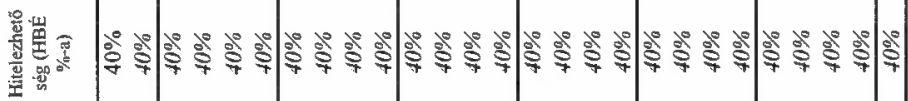

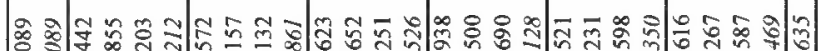

崖

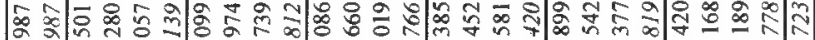

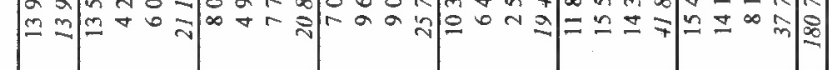

震震

훌

형 ₹

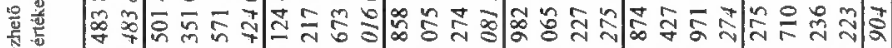

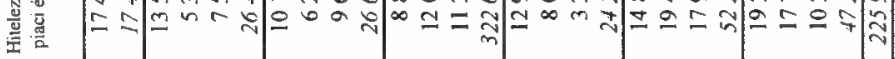

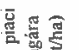

윤 8

귱

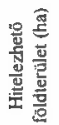

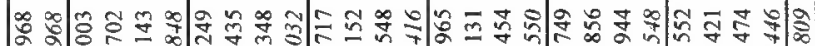
品

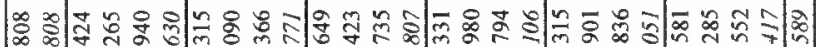

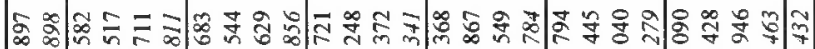

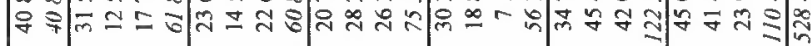

疍

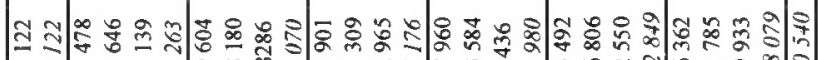

ริ ,

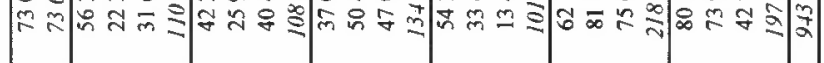

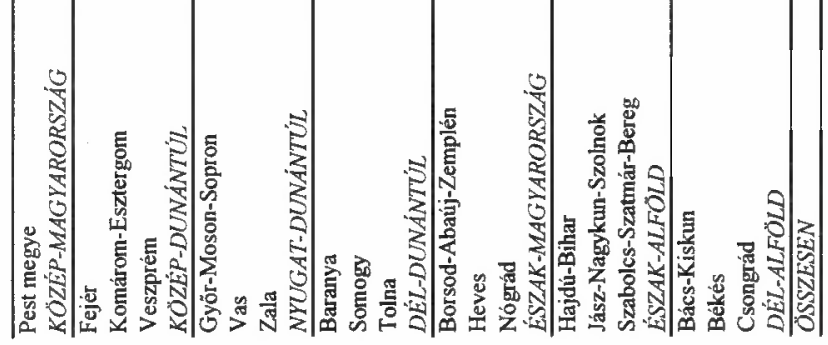


A kapott eredményeket azonban óvatosan kell kezelni, mert megtévesztőek lehetnek. Egyrészt az egész ország területére nyilvánvalóan nem érvényes egyformán az 500 eFt-os hektáronkénti termőföldár. Ha pontos adataink lennének az egyes megyék átlagos földárairól, akkor a modell alkalmas lenne annak befogadására és használatára is. Másrészröl a földterületek elaprózottságának mértéke sem azonos az egyes megyékben. Ebből következöen az 5 hektár alatti területek megyénként eltérö mértékben esnek ki a hitelezhető földterületek köréből. Harmadrészt a regisztrált gazdák életkora szerinti megyénkénti és régiónkénti eltérések is módosíthatják a kihelyezhető jelzáloghitel értékét. Ahol a gazdák magas életkora miatt sokan esnek ki a hitelezhető körböl, illetve, ahol a kieső gazdák nagyobb átlagos birtokméreteken gazdálkodnak, azokban a megyékben és régiókban jelentősen csökken a kihelyezhető hitelösszeg.

Az életkorra és a birtokméretekre vonatkozó pontos regionális egyedi alapadatok sajnos nem állnak rendelkezésünkre. A regisztráció érdekében kitöltött és benyújtott nyomtatványokon a megyei FVM hivatalokban ugyan zömmel hozzáférhetőek lennének az adatok, de a hivatalok ilyen irányú adatfeldolgozást még nem végeztek. Elsősorban a regisztrációs feltételeket ellenörizték, illetve az FVM által megkövetelt jelentésekhez szükséges adatfeldolgozást végezték el (6. táblázat). Mindebből következően a megyénkénti és régiónkénti jelzáloghitel kihelyezési lehetőség pontosabb meghatározásához az elemi adatok szintjéig, az egyéni regisztrációs lapokig lenne szükséges kiterjeszteni a vizsgálatot. Ha ezek az adatok rendelkezésünkre fognak állni, akkor a modell tovább finomítható, feltételezései pedig szükíthetőkké válnak. A regisztrációs adathalmazból a modell finomításához a legfontosabb adatok azok lennének, amelyek a paraméterek egymáshoz való kapcsolódásáról informálnak bennünket (paraméterek közötti korrelációs egyuitthatók).

A modell alkalmazási feltételei között az egyik kritikus pont a földterületek életkor szerinti megoszlása. Úgy gondoljuk, hogy a földjelzálog-alapú hitelezésben nem lenne feltétlenül szükséges a gazdák életkor szerinti megkülönböztetése, de mivel a jelzálogbankok alkalmazzák ezt a differenciálást, így a Pest megyei adatok felhasználásával számításokat végeztünk e téren is.

A Pest megyében regisztrált 1292 fó családi gazdálkodó köréből 1021 fỏ esetén rendelkezésünkre állnak az életkori és a földhasználati adatok. Ezen adatok alapján a használt termöföld életkor szerinti megoszlására végeztünk számításokat (1., 2. ábra).

Az elemzés azt mutatja, hogy a gazdák átlagéletkora csaknem 50 év (49,71 év). Az életkor szerint normális eloszlást követve szóródik a 20 és 93 éves kor közé eső sokaság. 
Kökényesi László : A tőkeáramlás egyik lehetséges csatornája a termőföldalapú jelzáloghitelezés.

Tér és Társadalom 18. évf. 2004/1. 93-106. p.

TÉT XVIII. évf. 2004

Gyors ténykép

103

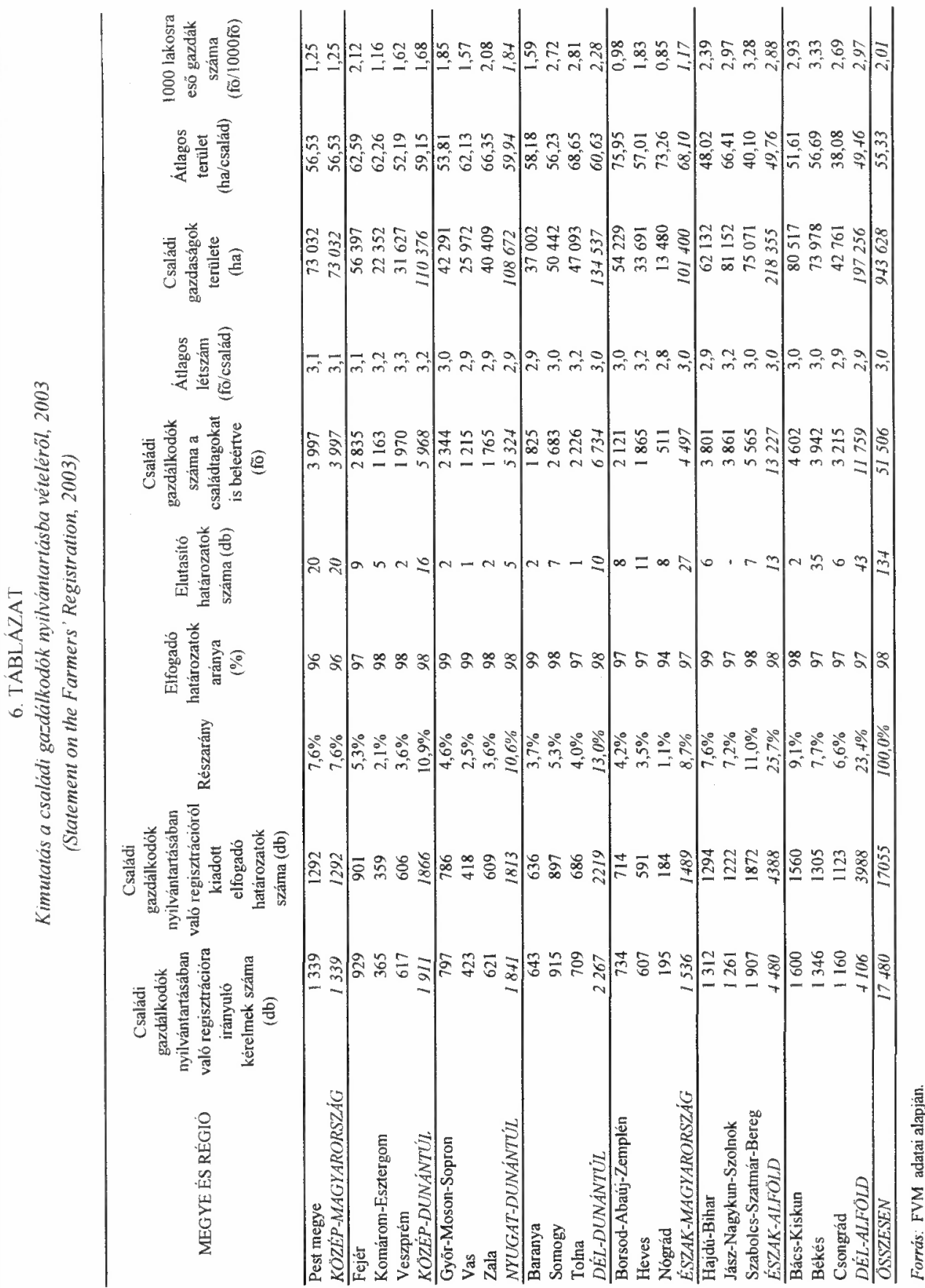




\section{1. ÁBRA}

Pest megyei gazdák száma és átlagos földterülete életkor szerint (The Number of Farmers and Their Average Arable Land in Pest County by Age)

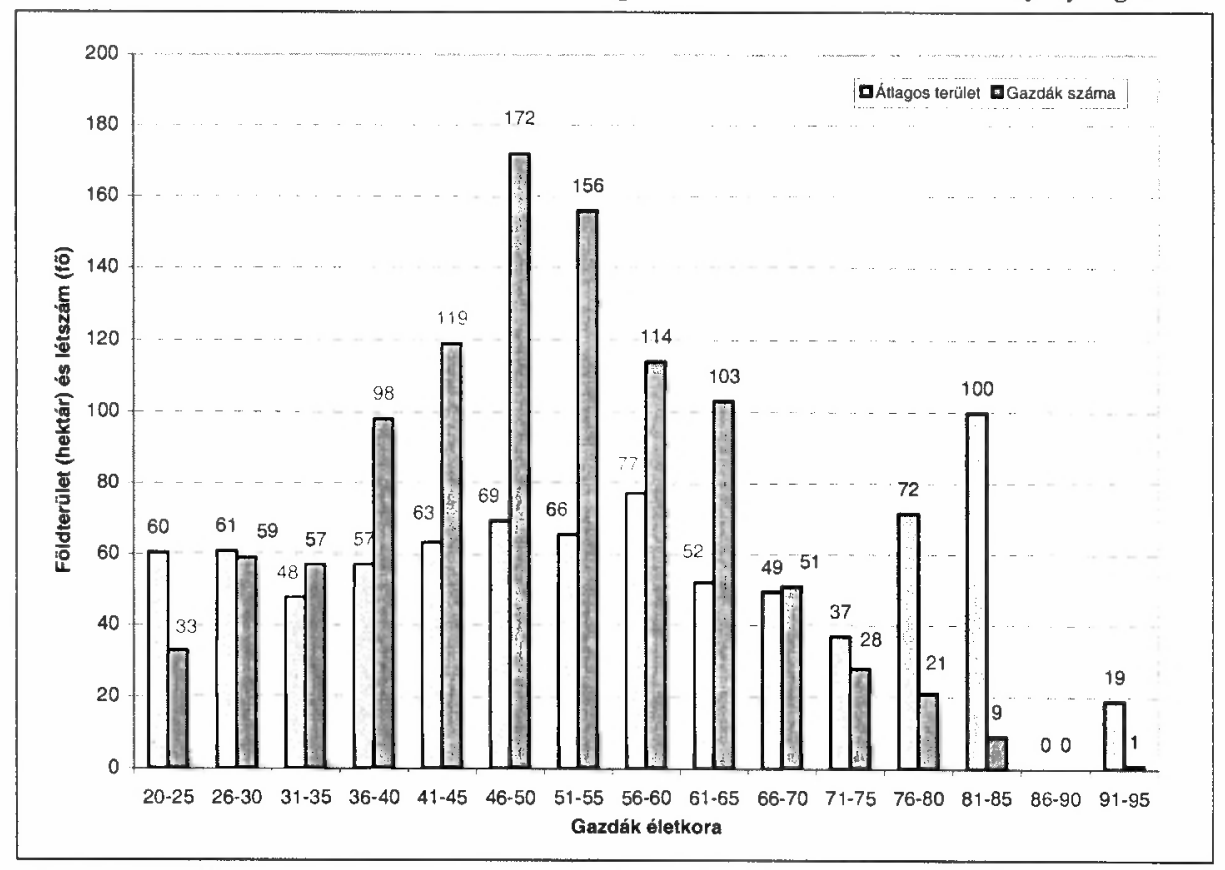

Forrás: Pest Megyei FVM Hivatal.

Figyelembe véve, hogy a 60 éven felüliek a jelenlegi feltételek szerint nem lennének hitelezhetőek, így a gazdák 20,8\%-a kiesik a potenciális ügyfélkörböl. Mivel azonban néhány kiugró adatot leszámítva az életkor szerinti földhasználat is normális eloszlást mutat, így velük csupán a földterületnek csak 17,8\%-a kerül ki a hitelezhetö körböl.

A Pest megyei fenti eredményhez hasonló megoszlást mutatott egy 2000-ben Jász-Nagykun-Szolnok megyében készült, 1000 fős mintára kiterjedő vizsgálat is (Baranyi 2000). Az életkori és földhasználati kérdésekre értékelhető választ adó 590 fỏ vizsgálatakor 3 életkori csoportot (0-25 év, 26-61 év, 62 év és felette) alkalmaztak. Az adattáblák újraelemzésével arra a megállapításra jutottunk, hogy a Jász-Nagykun-Szolnok megyei mintában a 62 éves és idősebb gazdák aránya 12,2\% volt, és az általuk használt földterület az összes használt földterület 9,33\%-át tette ki. Feltételezve itt is az életkor szerinti normális eloszlást, megfogalmazható, hogy megalapozott a konstruált modell azon feltétele, miszerint a gazdák $80 \%$-a megfelel az FHB életkor-kritériumának. A potenciális termőföldbázisnak pedig 15-17\%-a esik ki a hitelezhető körböl azért, mert használóik életkora a 60 évet meghaladja. Meggondolandó lenne, hogy az életkor-kritérium van-e olyan fontosságú hitelezési feltétel, hogy miatta ilyen mértékben szüküljön a hitelezhetök köre. 
Kökényesi László : A tőkeáramlás egyik lehetséges csatornája a termőföldalapú jelzáloghitelezés.

Tér és Társadalom 18. évf. 2004/1. 93-106. p.

TÉT XVIII. évf. 2004 - 1

Gyors ténykép

105

\section{2. ÁBRA}

Földterület életkor szerinti megoszlása

(The Distribution of Arable Land by Age)

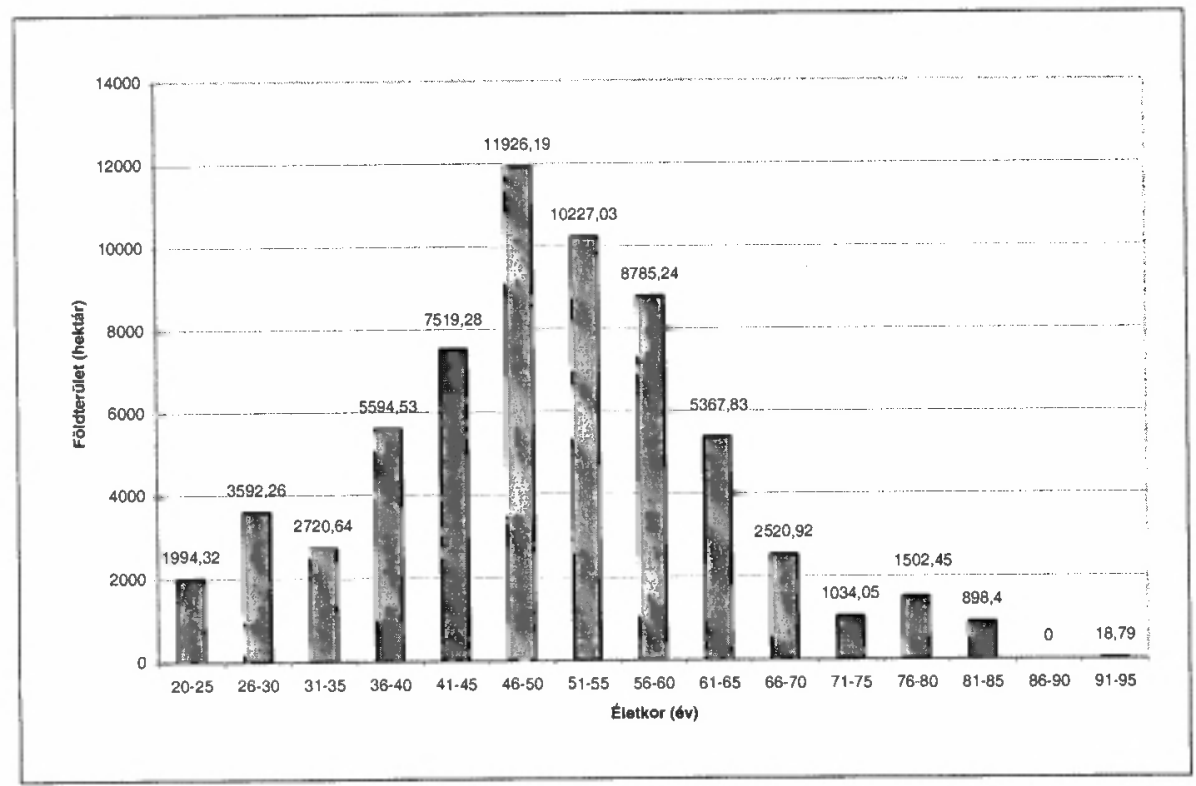

Forrás: Pest Megyei FVM Hivatal.

Az eddigi számítások alapján várható, hogy ekkora potenciális hitelpiacot tartósan nem fognak kihasználatlanul hagyni a jelzálogbankok. Különösen akkor lesz ez számukra kívánatos célpiac, ha megerősödnek ezek a vállalkozások, és beszükülnek a más irányú (pl. lakáscélú) hitelkihelyezések csatornái. Addig is kívánatos lenne, hogy lezajlódjon egy birtokrendezési folyamat, hogy a földterületek elaprózottsága miatt ne legyen korlátozva a hitelképesség. Így bővülne a hitelezhetỏ kör, és másik oldalról pedig javulna a gazdák finanszírozási lehetősége is.

$\mathrm{Az}$ is indokolja a termőföldfedezet elötérbe kerülését, hogy létrejött a jelzáloghitel-intézetek és a Nemzeti Földalapkezelő Szervezet (NFA) között egy megállapodás, amely értelmében az NFA szerződésben vállalt kötelezettség szerint, elöre kiszámítható értéken és kiszámítható időben megvásárolja a fedezetül szolgáló termöföldet, ha az adós nem törleszt, vagyis, ha a hiteltartozás rendezésébe a fedezet bevonásra kerül. Ez úgy válik lehetségessé, hogy a fedezetértékelést a hitelt nyújtó bank az NFA által közzétett vagyonértékelői névjegyzéken szereplö szakértők valamelyikétöl rendeli meg. A fedezetértékelést az NFA saját rendszerén belül felülvizsgálja, majd nyilatkozik arról, hogy az abban foglaltakat elfogadja-e. Amennyiben igen, úgy az NFA elkötelezi magát arra, hogy szükség esetén a termőföldet az értékelés alapján megveszi. Ez a vásárlási garancia csökkenti a jelzálogbankok kockázatát és a szükséges eljárási költségeket. Közvetetten pedig szélesítheti a jelzálogbankok célpiacát, javíthatja az agrárvállałkozók finanszírozási helyzetét, és módosíthatja a tőkeáramlás irányát. 
Kökényesi László : A tőkeáramlás egyik lehetséges csatornája a termőföldalapú jelzáloghitelezés.

Tér és Társadalom 18. évf. 2004/1. 93-106. p.

106 Gyors ténykép

TÉT XVIII. évf. 2004

\section{Irodalom}

Alvincz J. (2002) Családi a társas ellenében. - Piac és profit. 9. 4-8. o.

Baranyi A. (2000) Agrárvállalkozók Jász-Nagykun-Szolnok megyében. Kézirat.

Borszéki Éva (2003) Az agrárgazdaság jövedelmezóségi és felhalmozási viszonyai. - Gazdálkodás. 4. 2-14. o.

Burgerné Gi mes A. (2002) A mezögazdasảg tókeellátottsága. - Gazdálkodås. 4. 22-28. o.

FHB Rt. Éves Jelentése. $(2000 ; 2002)$ Budapest.

Graf von Berufstoff, C. (1997) Jelzálogjog az Európai Unió államaiban. - Magyar Jog. 10. 613-618. o.

Grill, W.- Perczynski, H. (1995) Wirtschaftslehre des Kreditwesens. Verlag Gehlen.

Magyar Statisztikai Évkönyv. (2000; 2002) KSH, Budapest.

Swain, N.J.-Andor M.-Kuczi T. (1996) Agrártermelés a falvakban a '90-es évek Kelet- Európájában. Szociológiai Szemle. 3-4. 125-147. o.

Prugberger T.-Olajos I. (2002) Termóföldbirtoklás, hasznosítás és forgalmazás a családi gazdaság elösegítésének új jogi szabályozása tükrében. - Magyar Jog. 5. 268-294. o.

Szûcs I. (2002) A földárak néhány elméleti kérdése napjaink hazai mezőgazdaságában. - Gazdálkodás. 1. 31-36. 0 .

Várhegyi É. (2002) Jelzáloghitel - kockázatok és mellékhatások. - Bank és Tőzsde. 16. 8-9. o. 